2019-06-07

Whose Right to the Smart City

Willis, Katharine S.

http://hdl.handle.net/10026.1/12729

10.1108/978-1-78769-139-120191002

Emerald Publishing

All content in PEARL is protected by copyright law. Author manuscripts are made available in accordance with publisher policies. Please cite only the published version using the details provided on the item record or document. In the absence of an open licence (e.g. Creative Commons), permissions for further reuse of content should be sought from the publisher or author. 
Willis, K (2018 in press). Whose Right to the Smart City? in Kitchen, R., Cardullo, P, di Feliciantonio, C (Eds). The Right to the Smart City. Emerald Publishing

\section{WHOSE RIGHT TO THE SMART CITY?}

\section{KATHARINE S. WILLIS}

Katharine S. Willis, Plymouth University, UK

Katharine.willis@plymouth.ac.uk

Katharine S. Willis is Associate Professor in the School of Art, Design and Architecture at Plymouth University, UK. Her research interests include smart cities, digital technologies and the role of space/place. She is co-author with Alex Aurigi of 'Digital and Smart Cities' (Routledge 2017) and leads the new MA in Smart Cities that will start in September 2019. 
Willis, K (2018 in press). Whose Right to the Smart City? in Kitchen, R., Cardullo, P, di Feliciantonio, C (Eds). The Right to the Smart City. Emerald Publishing

\section{ABSTRACT:}

This chapter works with Lefebvre's 'Right to the City' (1996b) to understand how a Smart City initiative was being implemented and as a consequence who benefitted. Whilst a model of citizenship is offered in smart cities, the 'actually existing' smart city in fact reconfigures models of citizenship in ways that instrumentalise technology and data that can reinforce patterns of exclusion for marginalised groups. Therefore, this chapter aims to understand how citizens participate in smart city projects and whether they can in fact they lead to the exacerbation of existing urban historical, material and social inequalities. The chapter focuses on some of those excluded by smart city projects; the urban poor, street traders and those who live in informal settlements and explores the way in which they access and participate in the city. In the Global South context, India is a key actor in implementing a national level smart city programme, and research was undertaken in the city of Chennai to investigate the way that the India Smart Cities Mission was being planned and implemented and the corresponding implications for marginalized communities. The chapter argues that there is a need to recognize the value of a range of everyday, small-scale ways in which citizens employ technologies and data that meet their needs in a social and spatially embedded context. In this way marginalized people may be empowered to have what Lefebvre describes as 'the right to the oeuvre, to participation and appropriation' (1996, p.173) in urban space.

\section{KEYWORDS:}

1. Smart city

2. participation

3. inclusion

4. marginalization

5. technology 
Willis, K (2018 in press). Whose Right to the Smart City? in Kitchen, R., Cardullo, P, di Feliciantonio, C (Eds). The Right to the Smart City. Emerald Publishing

\section{Introduction. The Right to the City}

This chapter works with Lefebvre's 'Right to the City' (1996b) framework in order to consider the role of everyday and people-centred agency in 'smart' urban transformation. Authors such as Aurigi (2012), Kitchin (2015), Marvin et al. (2016), Rose (2015), and Sassen (2012) have critiqued the technologically deterministic language of smart city rhetoric, focusing on the fact that it tends to focus on ICT solutions that are applied top-down. The smart city agenda rarely addresses issues of social differences in already-existing cities (Datta, 2018), and this chapter argues that it is critical to reflect on a question raised by March and Ribera-Fumaz (2014, p. 826): "whose smartness and whose cities?". The smart city approach tends to focus on technological solutions to urban problems from the perspective of states and companies, whereas these technologies "need to serve and work for people and communities ... in relation to setting local civic and infrastructural priorities" (Sadoway \& Shekhar, 2014). Although citizen consultation and participation are often described in smart city proposals, there is a marked dearth of effective mechanisms and technologies for public engagement with respect to issues of distribution of urban resources and amenities such as water, roads, street lights, drainage, waste services, and proposed smart solutions to them. In the Global South context, India is a key actor in implementing a national level smart city project that arguably leads to the exacerbation of existing urban historical, material and social inequalities (Datta, 2018; Ravindran, 2015; Sadoway \& Shekhar, 2014; Vanolo, 2014. The actual impacts of smart city projects include the displacement of informal groups from urban space, displacement and spatial segregation through land-use planning, reinforcing digital divides, gender disparities, and exclusion from the economic benefits of development. Therefore, taking the right to the city as a framework, the chapter represents an attempt to answer the question: 'Whose right to the smart city'?

The chapter focuses attention on some of those excluded by smart city projects - the urban poor, street traders and those who live in informal settlements. It draws on empirical work undertaken in India, Brazil and UK, focusing in particular on an examination of how Chennai in India is planning and implementing a smart city vision. Here, the India Smart Cities Mission (2016), a nationwide smart city project programme, shows evidence of driving inequalities by bringing about 'enclave' development that inordinately benefits private sector actors such as global ICT companies and wealthier populations over others (Datta, 2015). We outline two ways in which people are denied a right to the smart city: firstly through the proposed optimization, automation and privatization of urban services that seeks to centralize and drive out low paid and informal labour force; and secondly through cleansing and expulsion from the street space of street hawkers and those operating in the informal urban economy. Although this was a small scale and short term study, similar patterns of exclusion from participation and benefit from the smart city have been documented by other studies, such as those by Datta in India (2018), Wiig in Philadelphia (2016) and March and Ribera-Fumaz in Barcelona (2014).

\section{The Right to the Smart City?}

Lefebvre describes how "the right to the oeuvre, to participation and appropriation are implied in the right to the city" (1996b, p.173). Therefore, we cannot separate "the right to habitation" from the "right to participation": "the right of all city dwellers to fully enjoy urban life with all of its services and advantages ... - the right to habitation - as well as taking direct part in the management of cities" (Fernandes, 2007, p.208). Fernandez (ibidem) further unpacks this as a set of interrelated political rights that need to be fully recognized: the right to information; the right of 
Willis, K (2018 in press). Whose Right to the Smart City? in Kitchen, R., Cardullo, P, di Feliciantonio, C (Eds). The Right to the Smart City. Emerald Publishing

expression; the right to culture; the right to identity in difference and in equality; the right to selfmanagement, that is, the democratic control of the economy and politics; the right to public and non-public services. Rather than being an institutional right, such as the right to vote, the right to the city is rather something practiced by living out the routines of everyday urban life. Lefebvre's analysis further proposes a generalized form of self-management as the basis and expression of that right (2003: 150).

Lefebvre links the right to the city with the spatial concepts of the centre and the periphery. He argues that the centre creates a condition for the simultaneous presence of very different worlds and value-systems, of ethnic, cultural, and social groups, activities, and knowledge. The city is a social resource that creates the possibility of bringing together these different elements and making them productive as an essential device of the organization of society (Schmid, 2011). In a Lefebvrian framework, the centre can thus be defined as a place where "differences encounter, acknowledge, and explore one another, and affirm or cancel out one another; 'the right to difference'"'(Lefebvre, 1996a, p.34):

"The right to the city complimented by the right to difference and information ... the right of users [of multiple services] to make known their ideas in space and time of their activities in the urban area; it would also cover the right to the use of the centre; a privileged place, instead of being dispersed and moved to peripheries (for workers, immigrants, the 'marginal' and even for the 'privileged')."

Implicit in the 'right to the centre' is the possibility of expulsion to the periphery, displacement and exclusion from centrality. Therefore, exclusion is not just an effect caused by urbanization processes, but a much more fundamental rupture in the relationship between the city and its citizens. Lefebvre outlines how exclusion is based upon segregation "which rejects towards peripheral spaces all those who do not participate in political privileges. Equally, it stipulates the right to meetings and gathering" (Lefebvre, 1996b, p.30). This is reflected in urban space not just through ownership of property but through habitation in public space; city streets, parks and squares. According to Friedman, "a city can truly be called a city only when its streets belong to the people" (1993, p.39). Therefore, urban planning, or regeneration projects become critical processes where rights are either embedded or challenged. In fact, Harvey (2012, p.40) outlines how the right to the city is the right to control the urbanization process and to institute new modes of urbanization.

The smart city creates a new challenge to the right to the city. According to Shaw and Graham (2017 p.912) "the conceptual separation of a right to information from the right to the city is challenged by digital technology'....; digital information complicates Lefebvre's right to the city as a right to centrality". 'Therefore, there is a challenge of how to enable citizenship in the Lefebvrian sense through modes of digital participation. Shaw and Graham (2017, p. 908) further explain that "the power afforded to traditional actors of urban power - developers, planners, landlords - is now rivalled by the rise of new informational monopolies such as Alphabet Inc's Google". ICT providers, such as IBM, CISCO, Siemens and more recently Alphabet (Sidewalk Labs) have sought to position themselves as new actors in urban planning and regeneration projects.

\section{The right to participate: The efficiency paradigm for city services}

Smart City projects configure new relationships between citizens and city governance. The rationale of many smart city projects is grounded in a rhetoric where urban challenges are seen as 
Willis, K (2018 in press). Whose Right to the Smart City? in Kitchen, R., Cardullo, P, di Feliciantonio, C (Eds). The Right to the Smart City. Emerald Publishing

urgent and growing 'problems' that require fixing. Digital technology is seen as a 'solution', offering a new relationship between citizens and authorities, between governments themselves and common residents through better ways of communication and improved systems and services. This can happen on a range of levels. At a very basic level, cities can be seen as a local social information infrastructure, providing information about the 'real' city to inhabitants. In a model of civic engagement and participation, smart technologies and systems are seen to enable new modes of citizenship. There is much debate as to whether these new, digital forms of governance and participation actually deliver the active level of participation that they promise or whether in fact they are just as limited in their approach as traditional models of governance (Willis \& Aurigi, 2017).

The gap between the rhetoric of the smart city around governance and the reality of what is delivered has been highlighted by authors such as Kitchin $(2015, p .132)$ who points out that "smart city advocates imagine themselves as creating technologies, techniques and visions that are scientific, objective, commonsensical and apolitical." Whilst digital technologies and platforms might often be presented as 'tools' that enable certain forms of participation and governance, in fact they are far from neutral and introduce new models of democratic engagement in the city. Indeed, underlying much smart city visioning is a new model of urban management that is delivered through an efficiency paradigm for city services (IBM, 2012). Gathering, accessing and analysing urban data is championed as a process which leads not just to 'solving' city problems but saving money, time and resources as highlighted in IBM's early marketing strategies around the smart city. The premise of these management systems is that 'smart' delivers a more efficient management of city infrastructure, which in turn delivers better governance through better services. This should enable a more inclusive pattern of participation in smart city projects. However, this discourse is also opening up new tensions in the relationship between public and private sector in the management of cities. For example, IBM's and other corporate IT firms' strategies are designed going to establish these companies as partners in the delivery of future smart development. The promise of participation offered within these new coalitions of public and private actors masks an economic imperative where the actual beneficiary of the smart city are often the corporate partners rather than citizens. The reality can be quite different, as Kitchin (2015, p. 132) highlights:

Left untouched are issues such as panoptic surveillance, technocratic and corporate forms of governance, technological lock-ins, profiling and social sorting, anticipatory governance, control creep, the hollowing out of state provided services, widening inequalities and dispossession of land and livelihoods.

In the digital or smart city discourse, producing 'smart cities' inevitably also co-produces what we could call a 'smart citizen', which means that people have to be willing to adapt to, and to live in, smart cities. Vanolo (2014a, p. 893) highlights how this leads to patterns of exclusion since there is "little room for the technologically illiterate, the poor and, in general, those who are marginalised from the smart city discourse". The smart city agenda therefore is not neutral, but has an effect on the way citizens are supposed to behave, and in fact contributes to a lack of participation for those who arguably should be the beneficiaries of smart city initiatives: the urban poor and marginalized groups. Therefore, there is a need to critically address how people participate by taking a direct part in the management of cities in smart city projects, since "despite the re-orientation towards creating 'smart citizens' to date there has been little critical conceptual scrutiny as to how citizens are imagined and engaged by different smart city technologies" (Cardullo \& Kitchin, 2018, p. 5). 
Willis, K (2018 in press). Whose Right to the Smart City? in Kitchen, R., Cardullo, P, di Feliciantonio, C (Eds). The Right to the Smart City. Emerald Publishing

designed se

\section{The right to centrality: The smart city at the margins}

Underlying the efficiency paradigm of the smart city agenda is the fact that the redistribution and allocation of resources are often not directed towards those who would most benefit, i.e. the most marginalized citizens. The technological efficiency model in fact catalyses a process which, in practice, further excludes those at the margins. This challenges the "right to participate" in the Lefebvrian sense, since "the right to the city legitimates the refusal to allow oneself to be removed from urban reality by a discriminatory and segregative organization" (Lefebvre, 1996b, p.195). Smart city rhetoric propagates the idea that technologies can and will provide the solutions to all of our multiple problems without fundamentally changing our lifestyles or challenging the structures which enforce and maintain such problems. The optimisation of services championed in the smart city model leads to access and benefits for a privileged sector of the urban population. This is because the vision of what a smart city is, is largely matched to the aspirations and world view of a particular set of actors and subset of the population (Vanolo, 2014b). If we take a Feenbergian view, then 'involvement with a technology makes certain interests salient. [...] Once enrolled in a network individuals are motivated to address its failings and in some cases they also acquire potential power over its development' (Feenberg, 2011, p.5). Technological development does not in itself overcome the broader challenges of the lack of technical skills, poor economic opportunities, and existing democratic divides (Mossberger, Tolbert \& Stansbury, 2003). It privileges those who fit into that certain space while excluding those who cannot or will not conform. In the smart city, there is little space for anyone at the margins to challenge, or even engage with the actually existing smart city. That is because the communities involved often lack the circumstances, access, and the understanding of the importance of technology for empowering themselves, either as individuals or as a collective: they lack agency (Melgaco \& Willis, 2017). Rather than just perpetuating existing divides the smart city can reinforce social inequalities, since informal or marginal populations often have limited access to existing technical and urban infrastructures.

\section{Case Study: Smart City Chennai}

In India, the Smart City Mission (SCM) ${ }^{1}$ is a national, multi-city programme, which proposes massive urban regeneration projects in one hundred Indian cities over the five years from 2016. Chennai was one of the first nineteen cities chosen in the SCM, and the city selected the neighbourhood of T Nagar for its area-based development (see Figure 1). T Nagar is Chennai's main shopping area, known for its Sari shops and organized around a central axis of roads (Figure 2). The aim is that this pilot area will serve as a model for smart city development for other areas of the city. 
Willis, K (2018 in press). Whose Right to the Smart City? in Kitchen, R., Cardullo, P, di Feliciantonio, C (Eds). The Right to the Smart City. Emerald Publishing

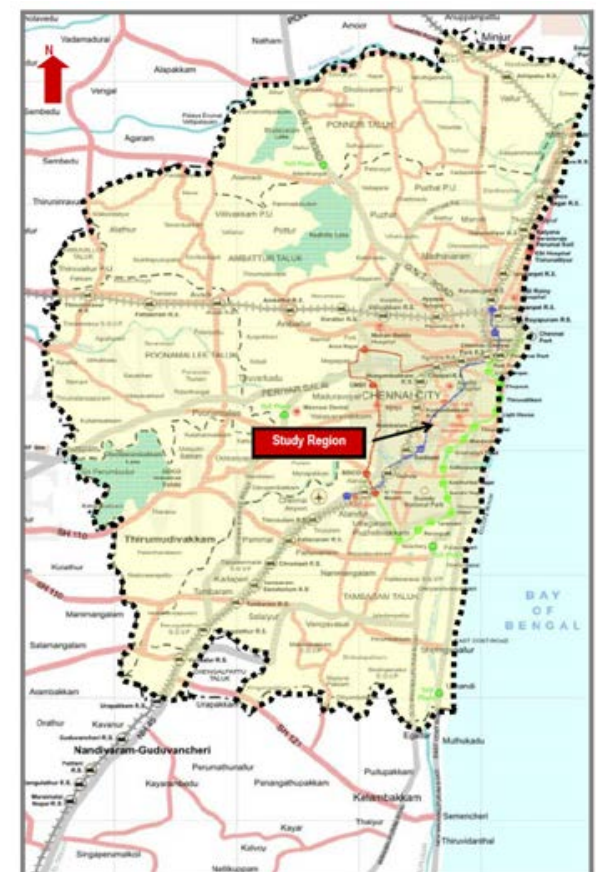

Figure 1: Map of Chennai with the location of T Nagar district highlighted.

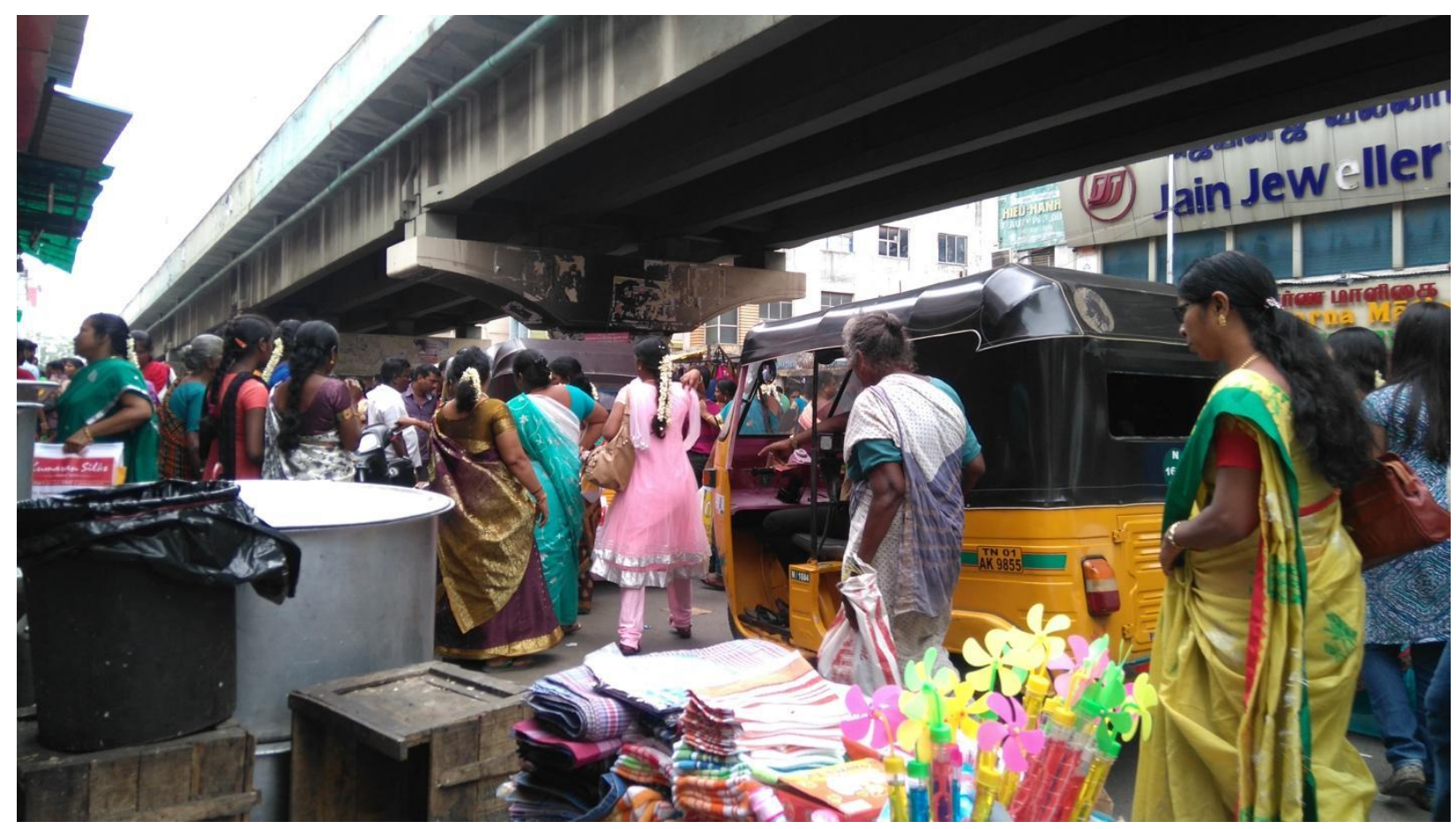

Fig 2. Street space in South Usman Road, T Nagar, Chennai (source: author)

As part of our research, we conducted two workshops designed to explore how the smart city was being conceived and implemented in practice. The workshops had two modes of enquiry: a stakeholder discussion and a mapping exercise. The discussion took place around the publicly available smart city documents and applications for the India Smart Cities Mission, and in particular 
Willis, K (2018 in press). Whose Right to the Smart City? in Kitchen, R., Cardullo, P, di Feliciantonio, C (Eds). The Right to the Smart City. Emerald Publishing

those documents relating to the Chennai proposal (2016). The stakeholder workshop had eighteen participants that included: Civic Consumer and Action group (CAG), a national activist group based in Chennai, local NGOs, academics, community IT organisations, architects, economists, urban planners and also representatives from the India National Street Hawkers Association. In particular, two things became clear: very few organisations or people knew of the actual detail of the Chennai Smart City plan; and the Chennai Plan appeared to be a re-purposing of the JNURM, a previous failed urban regeneration project (DASH, 2014). The second workshop consisted of a one-day mapping exercise where a group of approximately fifteen stakeholders visited the designated $T$ Nagar area to map the area to be implemented as part of the Chennai smart city plan. The participants included architects, community activists, local academics and the research network partners. The mapping exercise was meant to prompt participants to look at street level infrastructure in detail and visualize the ways in which the smart city proposal for Chennai could impact the area and conduct informal interviews with street hawkers and local vendors about their knowledge of the smart cities.

\section{Smart City Chennai: the urban efficiency paradigm}

The proposal for the area-based development plans of T Nagar is structured around the following 'components': pedestrianization, retrofitting of open spaces, footpath widening along main roads, cycle sharing network, multi-level car parks, integrating all the public transport, robust IT connectivity and digitization, smart bus/e-rickshaw feeders, solid waste management, water supply management, sewage management, e-Governance, and storm water management including flood warning and monitoring system (see Figure 3 ). The proposed solution to implement the initiatives, as outlined in the Smart City Chennai documents, is through the optimisation and automation of utilities (power, waste and water), transport and ICT infrastructure. The stated rationale for the Smart City Mission in Chennai is very much along typical lines of urban crisis, with a focus on infrastructure:

Chennai's infrastructure is under constant strain. Traffic bottlenecks, restricted civic amenities and high pollution are all characteristics of this strain on infrastructure (Ministry of Urban Development, 2016)

The approach adopted uses this rationale to implement a technological management of these apparent 'crisis' points in the urban infrastructure. The efficiency paradigm adopts the approach that current people-centred services are not only inefficient and unreliable; they are also not under control. In the following section, I compare the proposed initiatives in the Smart City Chennai proposal (see Figure 3) against the "actually existing smart city" (Shelton et al., 2015), observed through the mapping exercise in the T Nagar district. 
Willis, K (2018 in press). Whose Right to the Smart City? in Kitchen, R., Cardullo, P, di Feliciantonio, C (Eds). The Right to the Smart City. Emerald Publishing

\section{KEY COMPONENTS}

List the key components of your area-based development proposal (eg. buildings, landscaping, on-site infrastructure, water recycling, dual piping for water supply, etc.)? (max. 250 words)

- Assured Electrical Supply: Provision of $24 \times 7$ power supply with $10 \%$ from Renewable
energy source, Micro grid monitoring with smart consumer meters. Electrical \& ICT utility
Corridor along with smart metering
- Adequate Water Supply: Augmentation /Rehabilitation of old networks, reliable source
augmentation $24^{\star} 7$ water supply, DMA, $100 \%$ quality water meeting CPHEEO standards,
rehabilitation / replacement of water storage and distribution network. DMA based
distribution system including pressure and flow monitoring; special emphasis on
customer interactions and cost recovery. UFW reduction program.
- Waste Water Recycling: Waste water will be recycled and supplied to green spaces,
medians, gardens, etc. Treatment meeting CPHEEO standards and its reuse, Sensor
based monitoring of flows including automation of SPS and STP operations.
Augmentation / rehabilitation of Sewerage network and existing pumping stations
- Solid Waste Management: Convert exiting bins to sensor based bins; GPS installation
in vehicles to monitor the collection, introduction of 4 R concept (Reduce, recycle, reuse
and respond / refuse) - waste to energy, special emphasis on segregation of waste at
source
- Rain Water Harvesting \& Storm Water Management: Rain water harvesting (at
households and at community level) at an interval of every 30 mts, Augmentation of
existing storm water network along sensor based monitoring of flows.
- IT Connectivity \& Digitisation: WiFi connectivity for T Nagar, Digital signages and
billboards to intergrate all the public transport, Integration for all utilities including GIS
Conversions

Figure 3: Excerpt from Smart City Chennai proposals summarizing key components of the project (Ministry of Urban Development, 2016, p.27).

The solutions proposed for water, sanitation and electricity focus on supply-side problems and are premised on the use of meters and sensors to control utility flows. They fail to address the availability of these services for sections of the population.

Water supply is a challenge across India; in Chennai more than $15 \%$ of households do not have water supplied from a treated source, $5 \%$ do not have toilets, and $3 \%$ do not have waste water connections within their premises (source CAG). The SCM solution focuses on an automation of the existing system with a 'sensor based monitoring of flows' (see Table 1).

\begin{tabular}{|l|}
\hline Water \\
\hline $\begin{array}{l}\text { Adequate Water Supply: Augmentation / rehabilitation of old networks, reliable } \\
\text { source augmentation, } \mathbf{2 4 / 7} \text { water supply. }\end{array}$ \\
\hline $\begin{array}{l}\text { Waste Water Recycling: Waste water will be recycled and supplied to green } \\
\text { spaces, medians, gardens, etc. Sensor based monitoring of flows including } \\
\text { automation of SPS [Sewage Pumping Station] and STP [Sewage Treatment Plant] } \\
\text { operations. }\end{array}$ \\
\hline Rain Water Harvesting and Storm Water Management: Rain water augmentation \\
\hline
\end{tabular}


Willis, K (2018 in press). Whose Right to the Smart City? in Kitchen, R., Cardullo, P, di Feliciantonio, C (Eds). The Right to the Smart City. Emerald Publishing

of existing storm water network along sensor based monitoring of flows.

Table 1: Excerpt from Smart City Chennai proposal (Ministry of Urban Development, 2016, p.27)

Power supplies in Chennai are similarly unreliable, with regular citywide and statewide power cuts of 3-8 hours. A similar solution is presented for electricity infrastructure; again a $24 / 7$ uninterrupted supply is promised that will be achieved through sensor-based monitoring and smart meters (see Table 2).

Power
- Assured Electrical Supply: Provision of $\mathbf{2 4 / 7}$ power supply with $10 \%$ from
renewable energy source, micro grid monitoring with smart consumer meters,
and Electrical \& ICT utility Corridor along with smart metering

Table 2: Excerpt from Smart City Chennai proposal ('Ministry of Urban Development, 2016, p.27)

In the street, India has a remarkably localized infrastructure for power supply: transformers are located outside building blocks and much cabling is accessible, so that power grids are local and hackable. Whilst this is problematic in many ways, first because of the number of people who simply don't have electricity supply, in the district of T Nagar the power infrastructure is accessible so that can be managed by people at the scale of the street. The shift to a centrally-controlled and metered system removes the local interaction with the infrastructure.

\begin{tabular}{|l|}
\hline Waste \\
\hline Solid Waste Management: Convert exiting bins to sensor based bins; GPS \\
installation in vehicles to monitor the collection, introduction of 4R concept \\
(reduce, recycle, reuse and respond / refuse) - waste to energy, special emphasis \\
on segregation of waste at source
\end{tabular}

Table 3: Excerpt from Smart City Chennai proposal ('Ministry of Urban Development, 2016, p.27).

The pattern is replicated in the waste management proposals (see Table 3). RFID chips are proposed for solid waste management. This is a solution being delivered by a technology vendor and requires a 'control room' setup where full rubbish bins are reported through the system which then activates a rubbish collection. Yet, rubbish collection in Chennai is a people-centred service; involving both formal and informal labour at a neighbourhood and even street scale. By automating this service, it might create efficiencies by reducing formal sector labour costs but, as it has been found in previous projects, "expensive technologies create reverse institutional and systemic linkages that drive out the informal sector in order to pay for themselves" (CWG; GIZ., 2011). In addition, "privatization adds new large competitors to the waste sector and de facto transfers rights of access to waste resources from a public to a private domain" (WIEGO-Women in Informal Employment: Globalizing and Organizing, 2012). Water, power and waste components in the Smart City Chennai proposal are transformed from utility flows that are locally managed through people- 
Willis, K (2018 in press). Whose Right to the Smart City? in Kitchen, R., Cardullo, P, di Feliciantonio, C (Eds). The Right to the Smart City. Emerald Publishing

centric systems into services that are controlled and managed through automated and often privatized service pathways. In doing so, the informal economy and management of urban infrastructure at street level are effectively replaced by sensors and a centralized management structure. The financial resource, which previously focused around employment costs, is reprioritized to technology delivered and maintained often by private ICT providers; the utility service is optimized with the benefit (value) moving to the private sector. This process often goes hand in hand with the 'cherry picking' of lucrative customers and 'social dumping' of marginal ones (Marvin \& Graham, 1993, p.10).

\section{Smart City Chennai: exclusion from the centre}

The mapping exercise focused in particular on observing street spaces in order to understand who presently has the right to the space and how they might be affected by the implementation of the smart city Chennai project. What was observed (see Figure 2 ) is that the street space is currently a messy and somewhat chaotic, but consequently inclusive, space: in the Lefebvrian sense, as a place where "differences encounter, acknowledge, and explore one another, and affirm or cancel out one another" (Lefebvre, 1996b).

The street space accommodates street traders, rickshaw drivers, shoppers and a whole range of informal economic activities. Although not explicit in the smart city proposals, what became clear from a more detailed reading was that they constituted an urban 'cleansing' strategy that involved the exclusion from the public space of street traders, informal taxis and other workers in the informal economy. For example, street vendors, in particular, are articulated as a problem and the proposals include moving the traders en-masse into a separate building located out of the centre of the T Nagar district, quite literally displacing them from the centre to the periphery. As a consequence, the National Hawkers Federation had sought to mobilise its 40 million or so members across India to ensure their rights are recognised campaigning under the banner 'We want bread and butter not smart city' (see Figure 4).

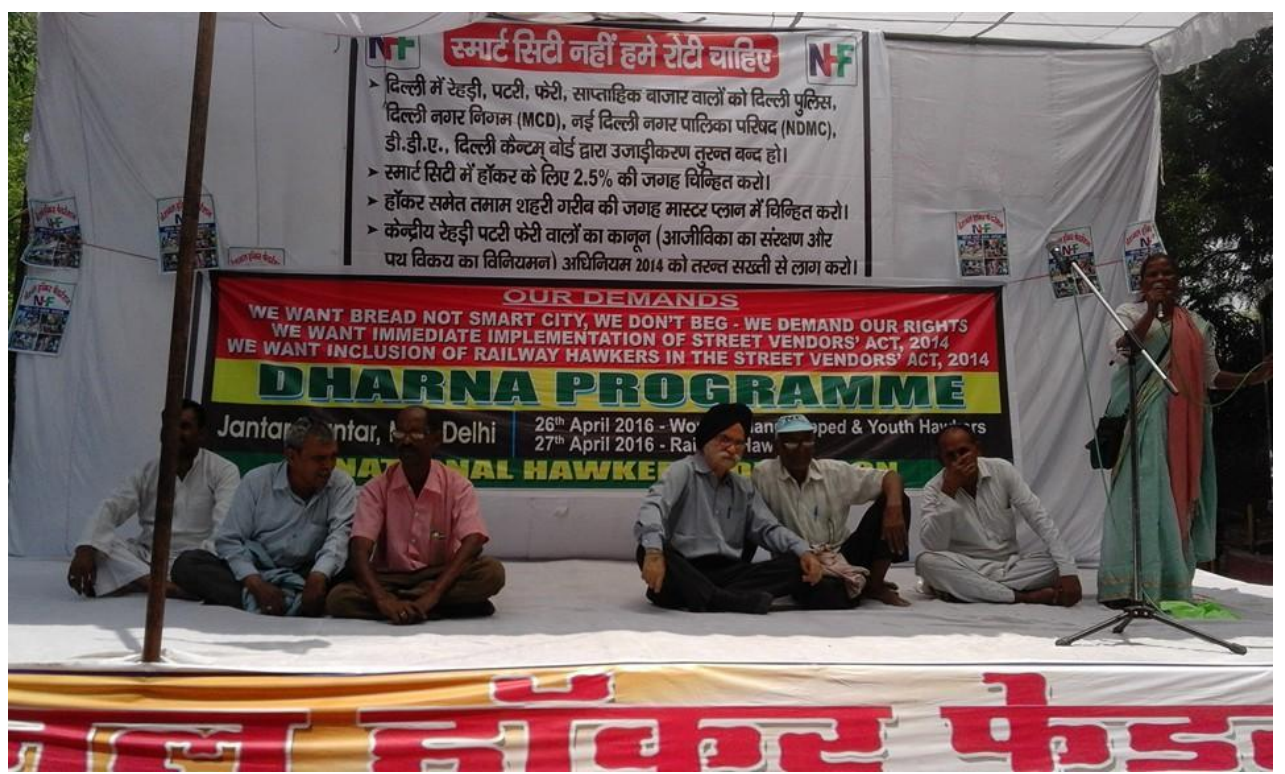

Figure 4: Banner: 'We want bread and butter not smart city' protest by National Hawkers 
Willis, K (2018 in press). Whose Right to the Smart City? in Kitchen, R., Cardullo, P, di Feliciantonio, C (Eds). The Right to the Smart City. Emerald Publishing

Federation April 2016 (source Facebook page)

Smart City Chennai proposals treat informal traders as 'encroachments' in the urban space and justify sanitising and exclusion of informal citizens using automated surveillance mechanisms to monitor streets. In this sense, "encroachments" can be seen as those who do not have the 'right to the centre', and such should be excluded to the periphery.

\section{Conclusion}

"Aren't cities and citizens already smart?"

(Sadoway \& Shekhar, 2014, p. x)

The smart city proposals for Chennai, it has been argued, reinforce and reproduce the spatial and economic exclusion of marginalized groups from the city space on a range of levels. The proposals fail to recognize or give value to the existing urban informality, where "informality must be understood as an idiom of urbanization, a logic through which differential spatial value is produced and managed" (Roy \& AlSayyad, 2011, p.233). They are driven and rationalized by technological quick fixes and technologically deterministic plan-making (Graham \& Marvin, 2001). Urban informality is treated as a set of conditions and resources that are equivalent to 'leaks' in a system that need to be optimized and rationalized. This may be one of the factors that has meant that many of the plans outlined in 2016 for the Smart City Chennai have failed to be realized. According to a press report in 2018 :

'The Minister said just one project of the Smart City Mission had been completed in Chennai in the past three years. "The Central government has given nod for 173 projects under Smart City Mission, estimated at $₹ 13,425$ crore. Out of the 173 projects sanctioned by the Centre, three have been completed in the State at ₹3.65 crore. (Special Correspondent, 2018)

The apparent failure in delivery of Smart City Chennai is one that it is echoed globally. The failure of digital technologies to solve urban challenges is linked to the strategy where technology is used to disenfranchise, fails to enable local knowledge, and black boxes devices and technical infrastructure (Haklay, 2013).

Taking the right to the city framework, then, Cardullo and Kitchin $(2018$, p. 20) identify that "the normative challenge to creating truly 'citizen-centric' smart cities will be to re-imagine the role citizens are to play in their conception, development and governance". The technology and governance model that underpins many smart technologies is, in fact, full of potential for marginalized groups - it is accessible, cheap and localized, utilising low cost sensors, cheap connectivity and shared data assets. If it wants to recognize the social capital of marginalized groups then it needs to involve not only engineers, coders or systems scientists "but also civic hacktivists, local associations and longstanding community groups that make up civic-cyber space" (Sadoway \& Shekhar, 2014). If urban informality is treated not as a condition, but as a "mode of production" within "sites of vibrant and entrepreneurial urbanism" (Roy, 2011, p.226) then it has the potential to reclaim 'smartness'. De Lange and de Waal (2019) highlighted the term "hackable cities" and Sassen refers to "open source urbanism" (Sassen, 2011) that includes low cost citizen sensing, crowdfunding platforms, open data initiatives and repurposed social media-based sharing 
Willis, K (2018 in press). Whose Right to the Smart City? in Kitchen, R., Cardullo, P, di Feliciantonio, C (Eds). The Right to the Smart City. Emerald Publishing

platforms.

In order to reclaim 'smartness' there is the urgent need for a public awareness programme that lets the general public behind the curtain of the smart city story and reveals the workings of smart technologies and infrastructures and that outlines some of the potential benefits. In doing so, this would recognize and celebrate some of the many ways in which cities and people are already 'smart', but which have not been given that name. Where cities often fail at smartness is in the role of urban planning, which inherently implies that infrastructure operates only to meet a predefined and fairly linear service or provision. Smart cities, to some extent, operate on the fly; their coordination based on resources available at the time and on what's needed. If smart cities could enable citizens to improvise and to tinker with their workings, then this could mark a shift to an 'actually existing' smart city. What we can learn from the Global South is that many of the informal communities that operate at the margins have developed exceptionally resourceful and innovative ways of using technology for their own benefit. Rather than a post-colonial 'shipping' of the western model of the smart city to the Global South, there is a great deal to be said for carefully observing, documenting and learning how urban informality adopts and works with technologies in a way that acknowledges that cities and citizens are already 'smart'.

\section{Acknowledgements}

The work in this paper is supported by the AHRC (Arts and Humanities Research Council) International Research network entitled "Whose Right to the Smart City" (whosesmartcity.net). The Chennai workshop took place on 16 June 2016 and was organized and led by Satyarupa Shekhar, Director of Government Outreach and Advisory, CAG, Chennai, India with support from Magdalena Cooper (intern). The report produced from the workshop is available here: https://whosesmartcity.net/publications-and-outcomes/ which was researched and documented by CAG, Chennai. Other partners and contributors in the network are Dr. Ava Fatah, University College London, UK and Dr. Ana Baltazar, Federal University of Minas Gerais, Brazil. We would also like to thank the many participants and contributors to the research network workshops, including those in Belo Horizonte (Brazil), London and Plymouth (UK) between 2017 and 2018. 
Willis, K (2018 in press). Whose Right to the Smart City? in Kitchen, R., Cardullo, P, di Feliciantonio, C (Eds). The Right to the Smart City. Emerald Publishing

\section{References:}

Aurigi, A. (2012). Reflections towards an agenda for urban-designing the digital city. Urban Design International, 18 (2), 131-144.

Cardullo, P., \& Kitchin, R. (2018). Being a 'citizen' in the smart city: up and down the scaffold of smart citizen participation in Dublin, Ireland. GeoJournal, online first, doi:

https://doi.org/10.1007/s10708-018-9845-8.

CWG; GIZ. (2011) The Economics of the Informal Sector in Solid Waste Management. Collaborative. Deutsche Gesellschaft für Internationale Zusammenarbeit (GIZ).

Datta, A. (2015). The Smart Entrepreneurial City: Dholera and a 100 other utopias in India. In C. McFarlane, S. Marvin \& A. Luque-Ayala, A. (Eds.), Smart Urbanism: Utopian Vision or False dawn? (pp. 52-70). London: Routledge.

Datta, A. (2018). The digital turn in postcolonial urbanism: Smart citizenship in the making of India's 100 smart cities. Transactions of Institute of British Geographers, online first, doi: https://doi.org/10.1111/tran.12225.

Feenberg, A. (2011). Agency and Citizenship in a Technological Society. Lecture presented at IT University of Copenhagen, available online: https://www.sfu.ca/ andrewf/copen5-1.pdf. last accessed?

Fernandes, E. (2007). Constructing the right to the city in Brazil. Social and Legal Studies, 16(2), 201219.

Friedmann, J. (1993). The right to the city. In M. Morse \& J. Hardoy (Eds.), Rethinking the Latin American City (pp. 135-151). Baltimore: John Hopkins University Press.

Graham, S., \& Marvin, S. (2001) Splintering Urbanism: Networked Infrastructures, Technological Mobilities and the Urban Condition. London: Routledge.

Haklay, M. (2013). Beyond quantification: a role for citizen science and community science in a smart city. In B. Campkin \& R. Ross (Eds.), UCL Urban laboratory pamphleteer. London: UCL.

Harvey, D. (2012). Rebel Cities: From the Right to the City to the Urban Revolution. London: Verso.

Kitchin, R. (2015). Making sense of smart cities: addressing present shortcomings. Cambridge Journal of Regions, Economy and Society, 8, 131-136.

de Lange, M. and M. de Waal, Eds. (2019). The Hackable City: Digital Media and Collaborative City Making in the Network Society. Singapore, Springer.

Lefebvre, H. (1996a). Writings on Cities. Oxford: Blackwell.

Lefebvre, H. (1996b). The right to the city. Writings on cities. Translated by Kofman, E. and Lebas, E., Cambridge, Massachusetts: Wiley-Blackwell. (to check because it seems the same as previous ref)

March, H., \& Ribera-Fumaz, R. (2014). Smart contradictions: The politics of making Barcelona a Selfsufficient city. European Urban and Regional Studies, 23(4), 816 - 830. 
Willis, K (2018 in press). Whose Right to the Smart City? in Kitchen, R., Cardullo, P, di Feliciantonio, C (Eds). The Right to the Smart City. Emerald Publishing

Marvin, S., \& Graham, S. (1993). Utility networks and urban planning: An issue agenda. Planning Practice \& Research, 8(4), 6-14.

Marvin, S., Luque-Ayala, A., \& Mcfarlane, C. (Eds.) (2016). Smart Urbanism - Utopian Vision or False Dawn? Abingdon: Routledge.

Melgaco, L., \& Willis, K. (2017). ICTs and Technical Agency: A Case Study of a Rural Brazilian Community. In M. Foth, M. Brynskov \& T. Ojala (Eds.), Citizen's Right to the Digital City (pp. 101117). Singapore: Springer.

Ministry of Urban Development, Government of India (2016). The Smart City Challenge Stage 2:

Smart City Proposal Chennai. Online document: https://smartnet.niua.org/content/2ccc073a-1c5f4c42-8f9a-a86ccb0bc8d8. last accessed?

Mossberger, K., Tolbert, C., \& Stansbury, M. (2003). Virtual inequality: Beyond the digital divide. Washington, DC: Georgetown University Press.

Ravindran, S. (2015) 'Is India's 100 smart cities project a recipe for social apartheid? '. The Guardian. $\quad$ https://www.theguardian.com/cities/2015/may/07/india-100-smart-cities-projectsocial-apartheid, 7 June 2015.

Rose, G. (2015). Smart cities and why they need a lot more social scientists to get involved. Available online: https://visualmethodculture.wordpress.com/2015/03/20/smart-cities-and-whythey-need-a-lot-more-social-scientists-to-get-involved/, 1 September 2018

Roy, A. \& AlSayyad, N. (eds.) (2004) Urban informality: Transnational perspectives fom the Middle East, South Asia and Latin America. Lanham, MD: Lexington Books.

Roy, A. (2011). Slumdog Cities: Rethinking Subaltern Urbanism. International Journal of Urban and Regional Research, 35(2), pp 223-238.

Sadoway, D. \& Shekhar, S. (2014) '(Re)Prioritizing Citizens in Smart Cities Governance: Examples of Smart Citizenship from Urban India'. The Journal of Community Informatics, 10 (3).

Sassen, S. (2011). Open Source Urbanism. Domus, June 29.

Sassen, S. (2012). Urbanising technology. In The Electric City Newspaper, available online: http://ec2012.Isecities.net/newspaper/: LSE Cities. 12-14.

Schmid, C. (2011). Henri Lefebvre, the right to the city and the new metropolitan mainstream. In N. Brenner, P. Marcuse \& and M. Mayer (Eds.), Cities for people not for profit: Critical urban theory and the right to the city (pp. 42-62). London: Routledge.

Shaw, J., \& Graham, M. (2017). An Informational Right to the City? Code, Content, Control, and the Urbanization of Information. Antipode, 49(4), 907-927.

Shelton, T., Zook, M., \& Wiig, A. (2015). The 'actually existing smart city'. Cambridge Journal of Regions, Economy and Society, 8(1), 13-25. 
Willis, K (2018 in press). Whose Right to the Smart City? in Kitchen, R., Cardullo, P, di Feliciantonio, C (Eds). The Right to the Smart City. Emerald Publishing

Special Correspondent (2018) 'Only 1 smart city project completed in Chennai in 3 years, says Minister'. The Hindu. http://www.thehindu.com/news/cities/chennai/only-1-smart-city-projectcompleted-in-chennai-in-3-years-says-minister/article22399821.ece, January 9.

Vanolo, A. (2014a). Smartmentality: The Smart City as Disciplinary Strategy. Urban Studies, 51(5), 883-898.

Vanolo, A. (2014b). Whose smart city? . OpenDemocracy, available online: https://www.opendemocracy.net/opensecurity/alberto-vanolo/whose-smart-city, 1 September 2018

WIEGO (Women in Informal Employment: Globalizing and Organizing) (2012) First Global Strategic Workshop of Waste Pickers: Inclusive Solid Waste Management. Cambridge, MA, USA. Available at: http://www.wiego.org/reports/first-global-strategic-workshop-waste-pickers-inclusivesolid-waste-management.

Wiig, A. (2016). The empty rhetoric of the smart city: from digital inclusion to economic promotion in Philadelphia. Urban Geography, 37(4), 535-553.

Willis, K. S., \& Aurigi, A. (2017). Digital and Smart Cities. London: Routledge. 